\title{
Issue emergence and the dynamics of electoral competition around immigration in Spain
}

\begin{abstract}
:
This article examines the changing dynamics of electoral competition around an increasingly salient issue in Spanish politics: immigration. We argue that, although the issue is close to a 'valence' one in terms of the views of the electorate, the behaviour of the three main statewide parties - analysed with data from party manifestos for the 1993-2011 period and of electoral campaign rhetoric between 2000 and 2011 - departs from the expectations of issue ownership competition. The result for the Spanish mainstream has therefore been a recurring ambivalence between adopting clear spatial positions on the issue and playing the competence card.
\end{abstract}

KEYWORDS: Immigration, Spain, issue ownership, party competition, elections.

Word count: Abstract=100; Text, figures and references $=8,591$; Appendices $=437$

FUNDING ACKNOWLEDGEMENT: The research leading to these results was carried out as part of the project SOM (Support and Opposition to Migration). The project received funding from the European Commission's Seventh Framework Programme (FP7/2007-2013) under grant agreement $\mathrm{n}^{\circ} 225522$.

(This is the pre-edited version of the Article published in Acta Politica. For citations, please refer to the journal version: Morales, L., Pardos-Prado, S. and Ros, V. (2014), Issue emergence and the dynamics of electoral competition around immigration in Spain, Acta Politica, advance online publication 29 August, doi: 10.1057/ap.2014.33) 


\section{INTRODUCTION}

How and when does the issue of immigration become incorporated into the mainstream party political agenda? What factors drive the changes in attention to and positions around the immigration issue? How well do contextual factors, as opposed to internal party factors, account for these changes? This article examines these questions by focusing on the Spanish case for the period comprised between 1993 and 2011.

Odmalm and Bale (201X) discuss three types of accounts for the ways in which mainstream political parties respond to the immigration issue. Environmental factors relate to the 'exogenous' shocks driving parties to respond by paying more or less attention to immigration in each electoral cycle; whereas 'endogenous' or 'intra-party' factors relate to the organizational constraints that parties face for adapting to the former exogenous shocks. A third, intermediate, account focuses on the dynamics of party competition, which are neither fully exogenous nor endogenous to political parties individually considered.

One first, obvious, external factor to consider is related to the trends and demographics of immigration. The magnitude of the migrant inflow to Spain between 2000 and 2008 suggests that parties could not ignore the issue even if they tried. In parallel, media attention increased, as well as a general concern about immigration among voters of all ideological persuasions. We know that the salience of immigration issues in the media can shape attitudes towards immigration among the public (Boomgaarden and Vliegenthart, 2009), and that immigration issues are attractive for the media (Brighton and Foy, 2007). It is reasonable to expect, therefore, that parties engage in competition over immigration debates especially when the attention, and the negative tone on immigration topics, are high in the media. Thus, in Spain, demand-side factors can be thought of as propitious for triggering a response from mainstream parties on the immigration issue.

In contrast, supply-side accounts focus on the importance of the electoral challenge by antiimmigration parties in stirring a reaction from mainstream parties on the issue of immigration (Meguid, 2005; Adams, Clark, Ezrow, and Glasgow, 2006; van Spanje, 2010, 2011). Spain 
is, however, a paradigmatic case of limited relevance of this factor. There has never been a significant anti-immigration party competing for seats at the national level. ${ }^{1}$

Among the internal or organizational constraints, Odmalm and Bale (cf. 2014) highlight the potential for internal ideological tensions emanating from including the immigration issue high up in the party political agenda (see also Bale, 2008; Bale, Green-Pedersen, Krouwel, Luther, and Sitter, 2010). As we will discuss in this article, while internal dissent in parties is always discernable on any issue, immigration has not proved a particularly divisive issue within Spanish mainstream parties. Thus, we do not expect that internal party divisions will be a major constraint to the strategic moves of Spanish mainstream parties on immigration. Consequently, we focus, primarily, on the relevance of demand-side external factors and how they shape the dynamics of party competition around the issue of immigration.

Both spatial and valence considerations will guide the empirical analyses shown below. As regards the former, spatial models of party competition understand issues as differences on positions along policy continuums. These continuums imply ideological differences between more or less restrictive positions towards immigration. The direction of preferences is usually required to be unequivocal for parties, and to be targeted at ideologically distinct electorates (Downs, 1957; Enelow and Hinich, 1984). As regards valence models of voting, the notions of issue salience and perceptions of party competence are considered as key determinants of party competition. Issue salience refers to the policy interests of the electoral bases to which parties respond, whereas party competence refers to the parties' reputation for solving problems associated with these policy interests. Salience and competence as determinants of voter and party behaviour are theoretically articulated by issue ownership theories (Petrocik, 1996). These theories predict that parties selectively emphasize those topics on which they feel they have a good reputation, and that voters will make their electoral choices on this basis (Budge and Farlie, 1983; Green-Pedersen, 2007; Bélanger and Meguid, 2008).

While spatial considerations would conceptualise immigration as a positional issue dividing different ideological stances across voters and parties, valence models would assume a high degree of consensus over policy outcomes. In this article, however, we do not assume $a$

\footnotetext{
${ }^{1}$ Radical right parties in Spain have only gained anecdotal political representation in local elections since 2003 (Llamazares and Ramiro (2007). The radical right has, however, been more successful at the local and regional level, especially in Catalonia (Hernández Carr, 2011).
} 
priori the positional or consensual character of the immigration issue in Spain. In fact, following one of the main aims of this special issue, disentangling the relationship between immigration preferences, salience and ideological considerations will be a central object of study. The overlapping or crosscutting nature of immigration attitudes vis à vis established ideological dimensions of political competition, like the left-right continuum, is contested in the literature (Kriesi, Grande, Lachat, Dolezal, Bornschier, and Frey, 2006, 2008; van der Brug and van Spanje, 2009). With which of these two descriptions of party competition around immigration the Spanish case fits better is an empirical question that we assess in this article.

The paper proceeds as follows. The next section describes the magnitude and nature of the sudden and massive increase in immigration to Spain between the late-1990s and the late2000s. We then follow with an analysis of the structure and trends in public opinion around immigration. Our results show that immigration is closest to a 'valence' issue with small differences in the preferences of voters of different ideological persuasions, and that the centre-right The centre-right People's Party (Partido Popular, PP) has a small advantage in terms of perceptions of competence. The fourth section uses data from an analysis of party manifestos and the electoral campaigns for the three main state-wide parties in the Spanish parliament - United Left (Izquierda Unida, IU), PP and the Socialist Party (PSOE) - for the period 1993-2011. The analyses show that most parties ignored the immigration 'issue' in their manifestos up until 2000 and then only noticeably increased their attention to it in 2008. We also show that increased party attention coincided with all parties converging towards slightly more restrictive positions. We then focus on the two main parties (PP and PSOE) and discuss why they decided whether to emphasize immigration during their election campaigns. In the final section, we address the research questions put forward by the editors of this special issue and examine the role of intra-party agreement, issue ownership, and issue overlap with the left-right dimension. We also discuss the difficult balancing of electoral gains and losses when handling the immigration 'issue' during campaigns, given that similarly to what happened to the Tories in Britain in 2005 - the PP's strategy to capitalize on anti-immigration sentiment in 2008 backfired and was not as successful as anticipated. 
The evolution of immigration to Spain has been recent and sudden. The foreign-born population increased in Spain from 1,067,478 in 1996 to 6,737,933 in 2012, which represents 14 per cent of the total population, from barely 2 per cent in 1990 and less than 4 per cent in 2000. This increase rapidly accelerated since 2000 and multiplied by five in less than a decade, entailing an average entry of around half a million individuals per year between 2000 and 2008 (see Figure 1).

Such an increase in a short period of time is unusual in other European countries and transformed Spain into a net recipient of immigrants from its previous status as a sender of migrants. Push (pre-existing links with some countries that became societies of high migratory pressure) and pull (an economic boom and an ageing population) factors favoured the inflow of migrant workers - mostly from Eastern Europe, Latin America and the Maghreb - resulting in a steep surge of the immigrant population in the country (Moreno, 2004; Cebolla and González, 2008).

The composition of immigration also substantially changed. The share of what now are EU15 countries decreased from 42 per cent of the foreign-born residents living in Spain in 1996 to less than a quarter in 2012. Immigration from new EU countries increased steadily from 1 per cent of the foreign-born population in 1996 to 17 per cent in 2012. The proportion of people from former colonial countries living in Spain increased steadily, especially in the early 2000s, and went up to 41 per cent of the foreign-born population. Moroccan immigrants were the traditionally largest immigrant group in Spain but their relative size has been reduced by successive waves of immigration from 16 per cent of the foreign-born population in 2000 to 11 per cent in 2012, even if the absolute number of Moroccan-born residents almost doubled in this period.

Finally, it is important to highlight that asylum seekers and refugees are not numerically relevant in Spain. This is in contrast to other west European countries studied in this special issue, where their presence and relative size is considerable and has contributed to the politicization of the issue of immigration. With less than 10,000 applications per year, asylum seekers and refuges constituted less than 1 per cent of the immigrant population in 1995 and 
proportionally their numerical relevance decreased to 0.04 per cent by 2012 . Hence, we will not focus on refugees and asylum seekers as a distinct category. ${ }^{2}$

Figure 1. Trends in the foreign-origin population in Spain

\section{Percentage of foreign born and foreign nationals}

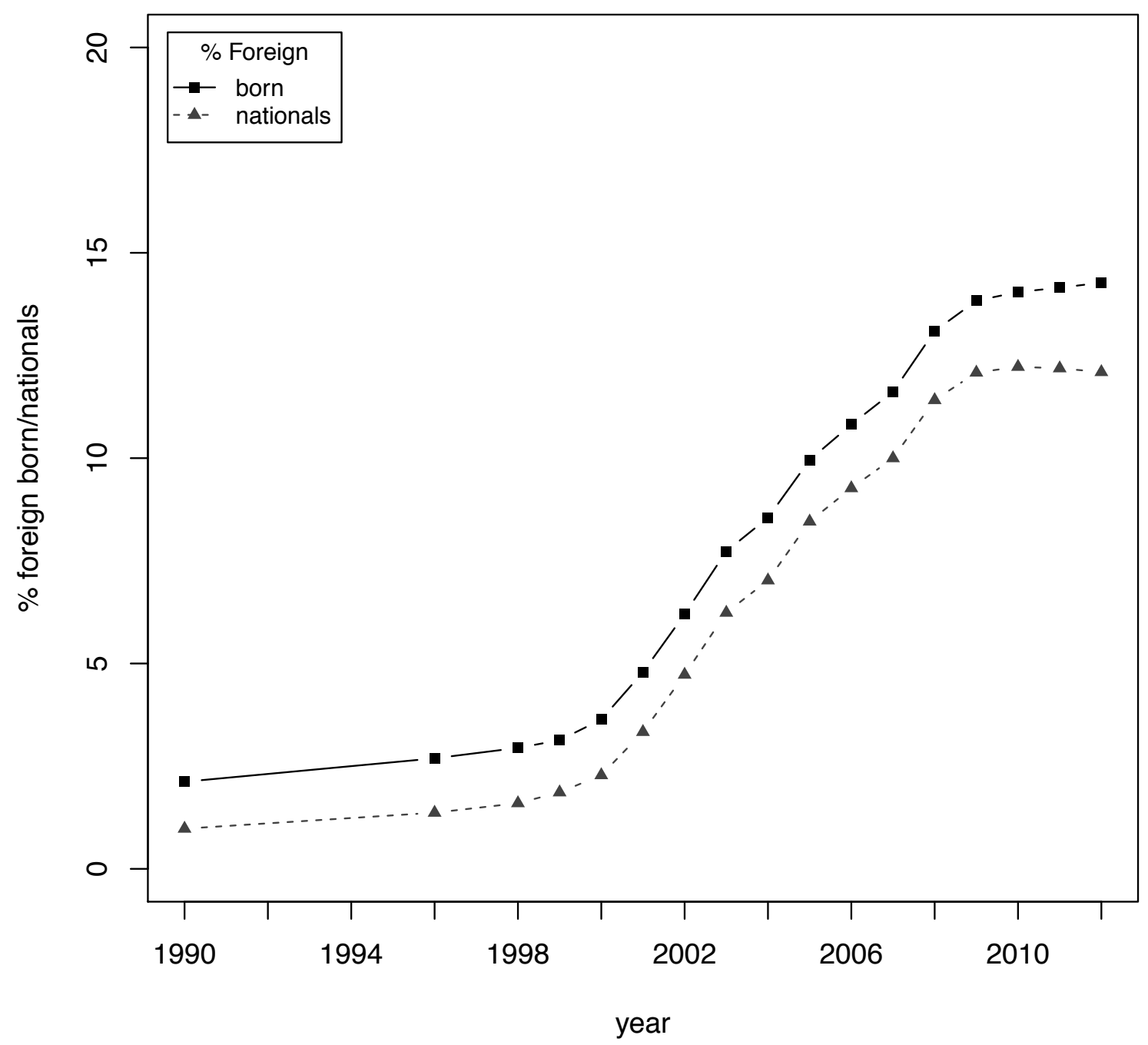

Source: Spanish National Statistics Institute, local population records (Padrón).

Note: Spanish population statistics also include 'unauthorized' migrants.

\footnotetext{
${ }^{2}$ Asylum application statistics in Spain are very poor and the number of applications is not made public. Information is only available on those that have been processed administratively. In 1995 the total such 'valid' applications were 3,294 and the highest number recorded in the period studied was in 2001 (9,489 applications). As a result, the number of individuals with legally granted refugee status living in Spain has always been very low, and ranging between 8,303 (in 1990) and 4,661 (in 2009). More detailed statistics can be found in Morales et al. (2012).
} 


\section{ISSUE SALIENCE AND PARTY COMPETENCE OVER TIME}

Before testing whether parties emphasize immigration following voters' perceptions, this section describes the evolution of immigration salience and perceptions of party competence in public opinion.

Figure 2 plots the evolution of the share of Spanish citizens considering immigration as the most important problem facing the country. The share of respondents who mentioned immigration as one of the three main problems rarely fell below the $10 \%$ threshold. The perceived importance of immigration in public opinion oscillated between 10 and $20 \%$ in the first half of the 2000s. However, between 2005 and 2008, public concern over the immigration issue increased remarkably, reaching a 60\% peak around September 2006. The level of concern dropped again, and fell below $20 \%$ in the last years of the period analysed.

It is interesting to note that immigration concerns did not necessarily increase when the economic crisis became salient in the public debate from the late 2008 onwards. It is precisely then when immigration concerns go down, reaching again their lowest levels. This pattern is very much consistent with the evolution of respondents mentioning immigration only as the first problem facing the country, and to a lesser extent also with the evolution of citizens mentioning immigration as the second or even third problem. ${ }^{3}$

Though the degree of concern with immigration in 2006 was quite extreme, the level of importance attributed to immigration during most of the period is not overwhelming in comparative terms. For example, in Britain, between 30 and 40 per cent of the population mentioned immigration as one of the most important problems facing the country in the 2002-2011 period, according to Ipsos-Mori Issues Index. And in Switzerland between 40 and 60 per cent have pointed to immigration and foreigners' integration as one of the five most important problems since 2000, according to the Sorgenbarometer.

\footnotetext{
${ }^{3}$ This massive drop in attention does not necessarily mean that cultural threat perceptions among the Spanish public have lost traction when the economy runs into trouble, as suggested by Bornschier (2010). Indeed, cultural threat perceptions increased gradually and continuously since the 1990s until 2006-2007. Unfortunately, all available time series are interrupted around 2007, but those that exist from the CIS immigration yearly surveys that started in 2007, slightly earlier than the economic crisis hit Spain, suggest that cultural threat perceptions either remained stable or continued to grow slightly after the crisis hit fully (surveys number 2731 , 2773, 2817, 2846, 2918 available on http://www.cis.es/).
} 
Figure 2. Evolution of immigration as the most important problem

Percentage who mention immigration as a problem

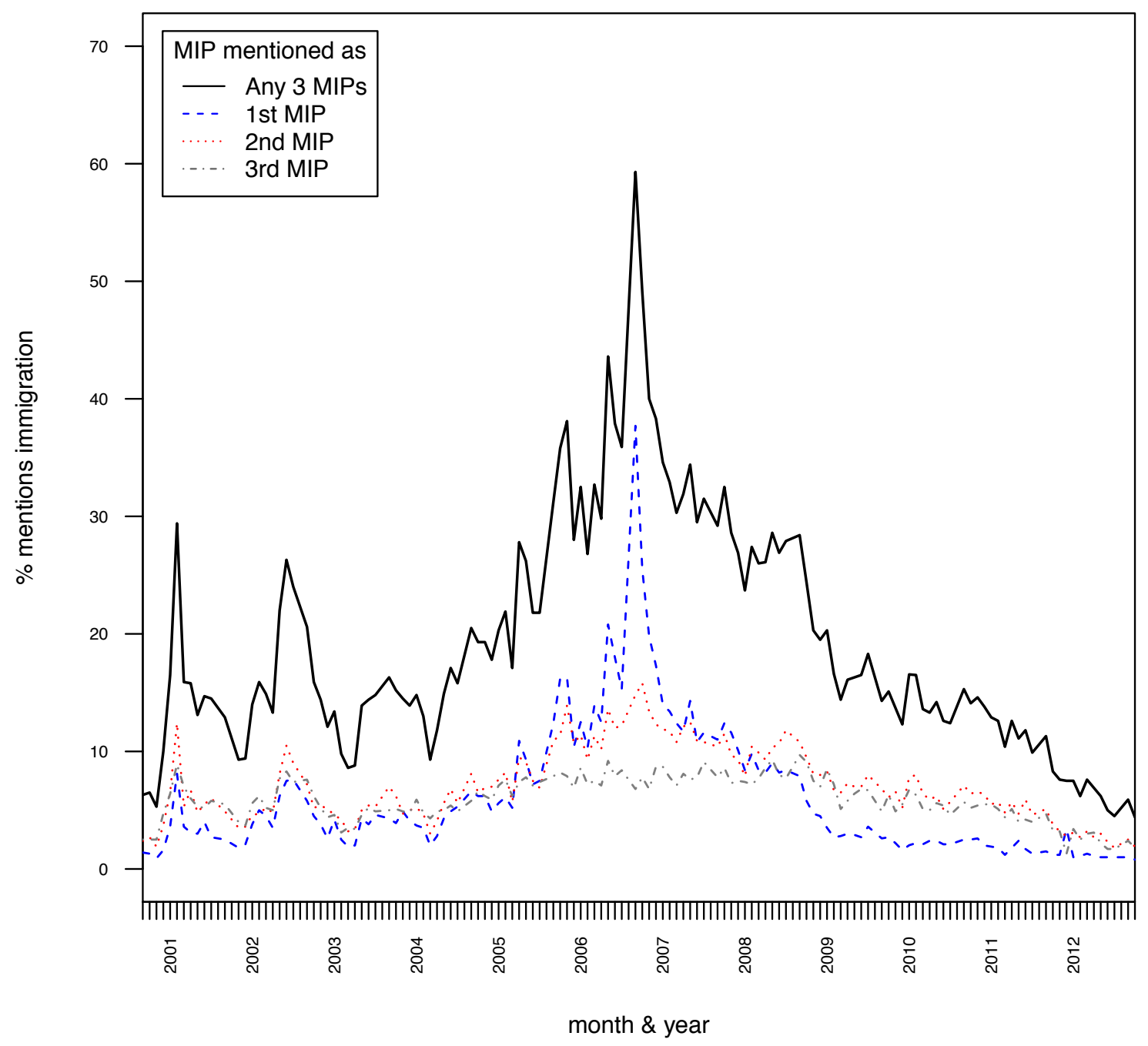

Source: CIS monthly barometer series.

While valence models of political competition stress the importance of issue salience, spatial theories of voting focus on the direction of public preferences over the immigration issue. Disentangling concern from attitudes towards immigration is thus a relevant step to understand the different mechanisms of politicisation of the immigration issue. Figure 3 plots the evolution of public attitudes towards immigration in Spain. The vertical axis corresponds to the share of respondents considering that there are too many people from other countries. The source of data is ASEP surveys from 1991 to 2007. Unfortunately, there is no more 
recent data available from the same source. This is why we extend the time series with CIS surveys containing a comparable indicator for the 2008-2010 period. The upper-left graph in Figure 3 shows the evolution of negative attitudes towards immigration for the full valid sample in each survey. While there was close to $15 \%$ of individuals considering that there are too many immigrants in 1991, this figure increased steeply and up to $65 \%$ in 2006 . The proportion of negative views on immigration moderately decreased after 2006, reaching levels close to $45 \%$ in 2010 . It is important to note that this evolution is comparable to that followed by immigration as the most important problem in the country. Both salience and negative attitudes increased until 2006 and decreased thereafter. This suggests that the salience of and negativity towards immigration were in lockstep, which chimes with Jennings' (2009) findings for Britain, and implies that valence considerations are not completely independent from positional features on this issue.

Indeed, the evolution of negative attitudes towards immigrants ${ }^{4}$ followed an almost identical pattern across left-right ideological spaces ${ }^{5}$ ). The slope of the evolution was steeper for voters on the centre and right of the ideological spectrum — with the latter reaching the highest levels of negativity beyond $70 \%$ around 2006 - but there was a relative increase in antiimmigrant feeling among voters across the ideological spectrum. ${ }^{6}$

\footnotetext{
${ }^{4}$ The expressions "immigrants", "foreigners" and "people from other nationalities" are used interchangeably in surveys in Spain. The wording of the item in the ASEP surveys is: "What would you say about the number of people from a different nationality, race, religion or culture that come to live to our country? Do you think that they are too many, many, not many, or not too many?" The wording of the CIS surveys is: "In your view, the number of immigrants currently in Spain is insufficient, acceptable, high, or excessive?".

${ }^{5}$ Operationalised on a 1-7 scale until 2007, and on a 0-10 scale from 2008 onwards. On the 1-7 scale, extreme left positions are 1-2, centre-left positions are 3, centre positions are 4 , centre-right positions are 5 , and extreme right positions are 6-7. On the $0-10$ scale, extreme left positions are $0-2$, centre-left positions are $3-4$, centre positions are 5, centre-right positions are 6-7, and extreme right positions are 8-10.

${ }^{6}$ Except for the peaks in 2006-2007, the negative attitudes towards the level of immigration in Spain were not too different to those found in Britain, for example, in the late 1990s. 27.5 per cent of Spaniards thought that there were 'too many' immigrants in Spain as compared to 22 per cent of British who said they strongly agreed that 'there are too many immigrants in Britain' (Ipsos-Mori race relations and immigration trends). However, whereas in Britain the percentage of respondents holding this view oscillated between 30 and 40 per cent throughout the 2000s, in Spain it ranged between 40 and 65 per cent. In France, for example, the equivalent response oscillated between 20 and 30 per cent in the 2000s. Nevertheless, this heightened perception of an excessive number of immigrants has co-existed with a relatively positive evaluation of the effects of immigration on the economy. Survey data from the European Social Survey indicates that Spaniards have appreciated the benefits of immigration for the economy much more than the British, Dutch and French until the start of the crisis in 2008, when their views have converged. See on this Méndez, Cebolla, and Pinyol (2013).
} 
Figure 3. Evolution of attitudes towards immigration by ideological self-placement
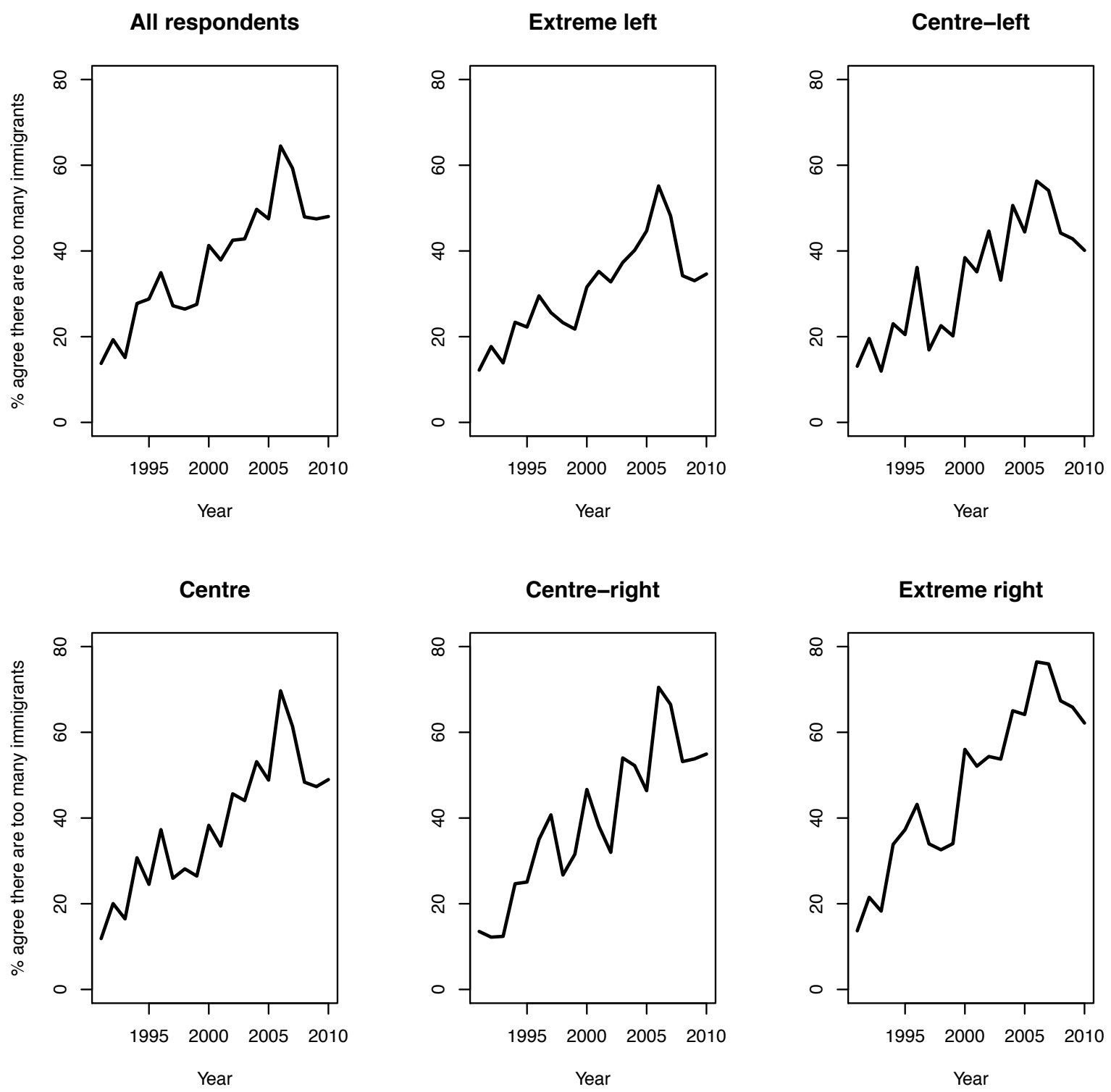

Source: ASEP monographic surveys on immigration, 1991-2007; CIS monographic surveys on immigration, 2008-2010.

Given the salience of and negativity towards immigration, how competent are the two largest mainstream parties perceived as being when it comes to immigration? Figure 4 shows citizens' competence attribution on immigration between 2006 and 2010. Unfortunately, this period coincides only with Socialist terms (March 2004-November 2011), and hence we do not have perceptions of competence when the PP was in power. The perception of the PSOE as the best party handling immigration follows a downward trend between April 2006 and July 2011, and their reputation falls 14 percentage points between October 2008 and October 
2010, during its second term in government. By contrast, the views on the PP as the best party to handle immigration followed an almost linear and positive trend. While only $29 \%$ of the electorate considered the main Spanish conservative party as the most prepared to manage the issue in April 2006, up to 42\% of the electorate considered so in July 2011, a few months prior to the legislative elections. ${ }^{7}$

Figure 4. Evolution of party competence perceptions by ideological self-placement

\footnotetext{
${ }^{7}$ The linear decrease of the PSOE's competence reputations on immigration matches the generalised loss of faith in this party. Competence reputations of the PSOE managing issues like employment, education, the health system, the economy and terrorism also went down significantly. Between April 2006 and July 2011, the number of people who thought that the PSOE outperformed the PP in managing employment went down by 20 percentage points. This loss was also quite remarkable for the economy $(17 \%)$ and terrorism $(15 \%)$, and a bit less dramatic for traditionally Socialist-owned issues like education $(11 \%)$ and the health system $(10 \%)$. The PP's issue competence reputation increased over the period analysed, even if it did not fully capitalise the PSOE's decline. When looking at the difference between 2006 and 2011, the PP was perceived as particularly more competent to deal with employment and terrorism (10\% increase), and more competent to deal with the economy $(7 \%)$, education $(6 \%)$ and the health system $(6 \%)$.
} 
All respondents

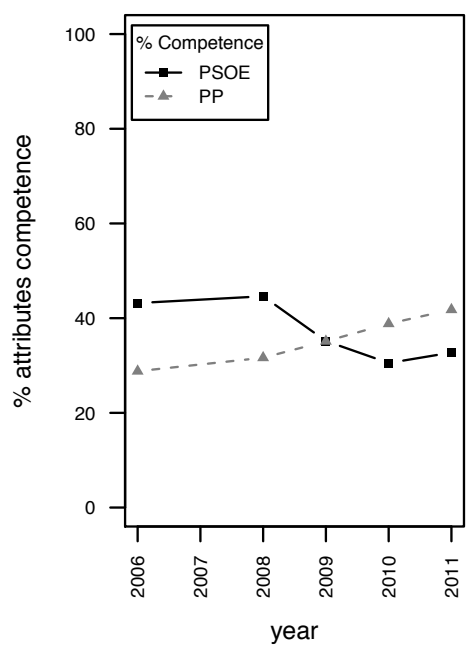

Centre

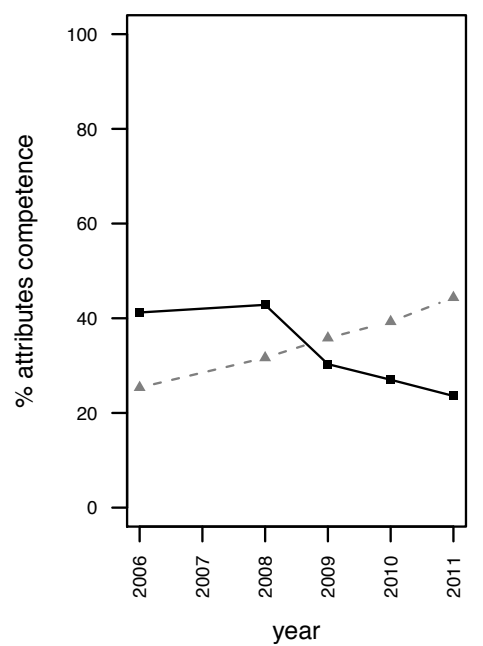

Extreme left

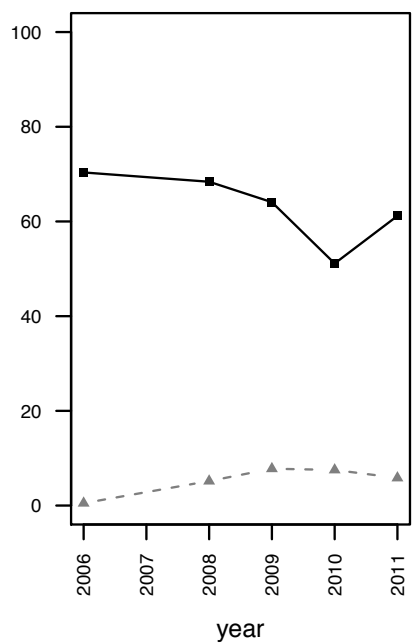

Centre-right

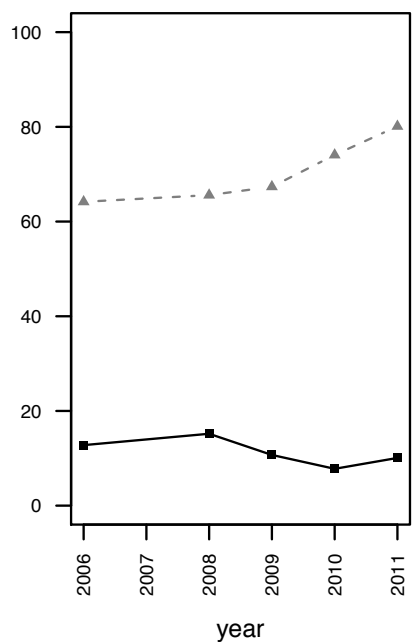

Centre-left

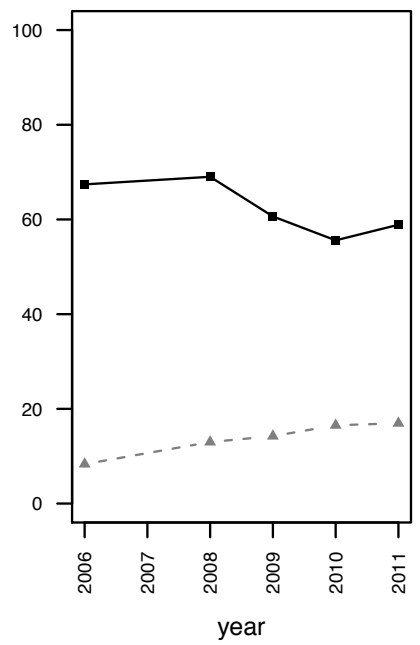

Extreme right

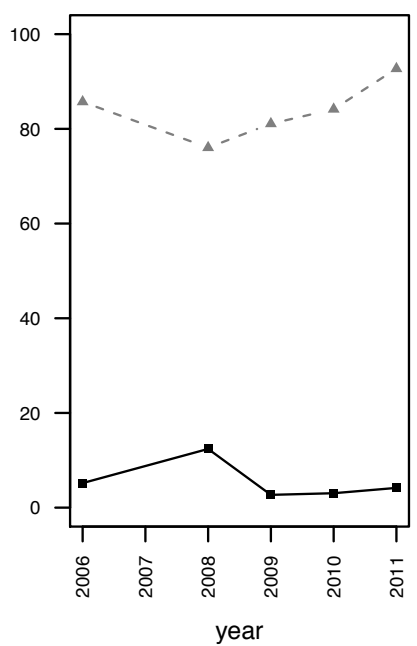

Source: CIS survey barometers (April 2006, October 2008, October 2009, October 2010, July 2011).

When we split the analyses by respondents' ideological self-placement, the Socialists' reputation experienced a quite steep downward trend between 2009 and 2011 among both extreme left and centre-left respondents, but is larger for the former (19 percentage points) than for the latter (13 percentage points). Yet, the largest relative drop in the perceptions of competence to deal with the immigration issue for the PSOE is observed among individuals who place themselves at the centre of the left-right scale. The difference between the highest and the lowest reputation score for this group reaches 19 points. More importantly, whereas the worsening of competence evaluations among left-wingers does not result in a relevant increase in the evaluations of competence of the PP, among respondents in the centre of the ideological spectrum almost all the losses in competence for the PSOE result in gains in 
competence evaluations for the PP. Whereas only $25 \%$ of individuals considered the PP as the best at dealing with immigration in April 2006, 44\% of respondents thought so in July 2011. What little credibility the PSOE had with centre-right and extreme right electorates they had almost completely lost by 2010. And in turn their evaluations of the competence of the PP were as high or higher than those of the left-wing citizens in relation to the PSOE.

The implication of these findings is that perceptions of immigration competence are not quite independent of ideological self-placements in Spain. Even if the evolution was the opposite for PP and PSOE respectively across almost all ideological groups, the degree of variability and the level of these perceptions are low in distant ideological spaces. Interestingly, however, and consistently with valence theories of party competition, perceptions of competence are likely to affect central electorates that do not consider themselves neither left nor right. Moreover, perceptions of competence seem to also vary a lot in the most proximal ideological space of each party. This means that competence perceptions are not fully a mirror image of ideological proximity.

Finally, we examine voters' evaluations of the actual immigration policy implemented in Spain with data from four post-election surveys between 2000 and 2011. Data for 2000 and 2004 refer to the evaluation of the policy implemented by the PP as the incumbent, and in 2008 and 2011 they refer to the policy implemented by the PSOE. The indicator reported in Figure 5 is the share of respondents considering the immigration policy implemented by the government as good or very good, minus the share of respondents considering that the main opposition party's immigration policy would have been better. However, the item concerning a hypothetical policy performance of the opposition party is not available for 2011, so just the share of respondents considering the government's policy as good or very good is reported. The substantive implications of Figure 5 do not change if only the share of positive evaluations of governmental policies is reported.

Figure 5. Evaluation of immigration policy by ideological self-placement 
All respondents

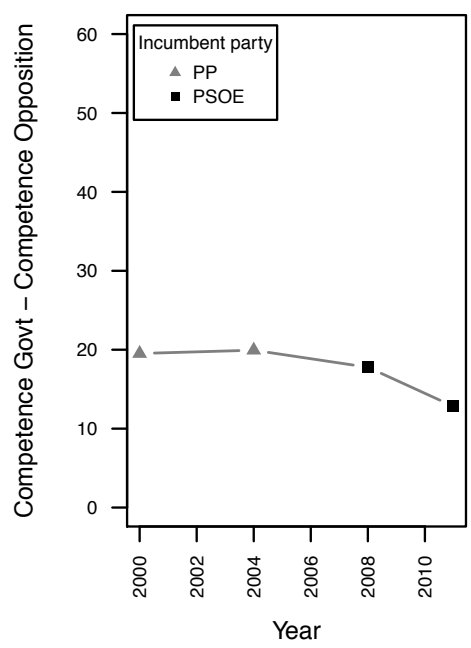

Centre

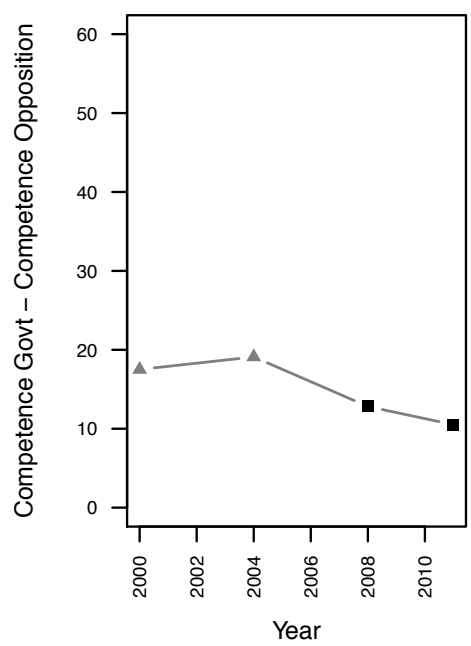

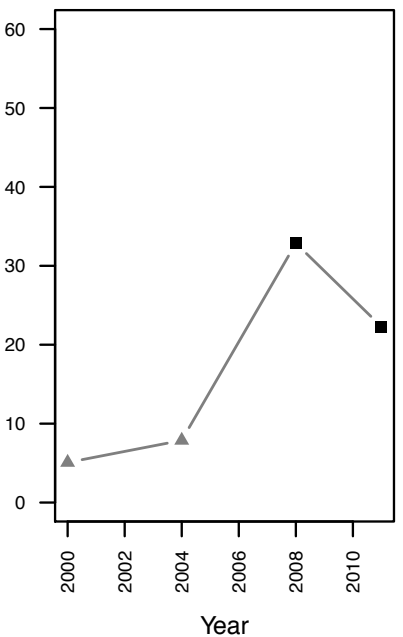

Centre-right

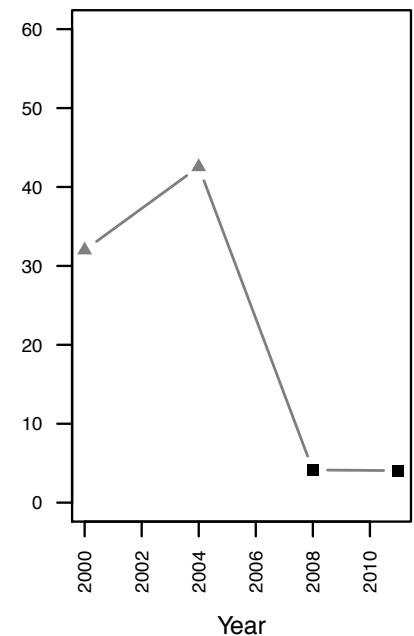

Centre-left

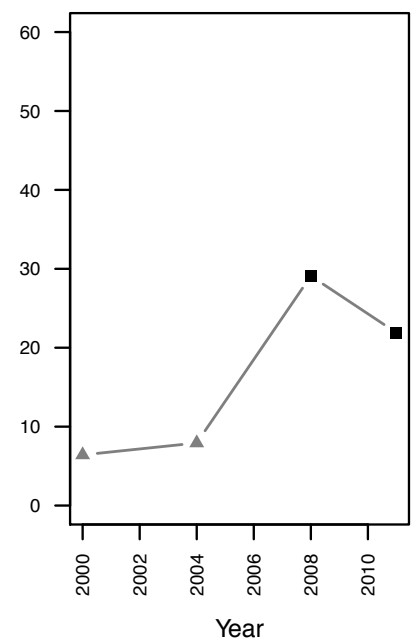

Extreme right

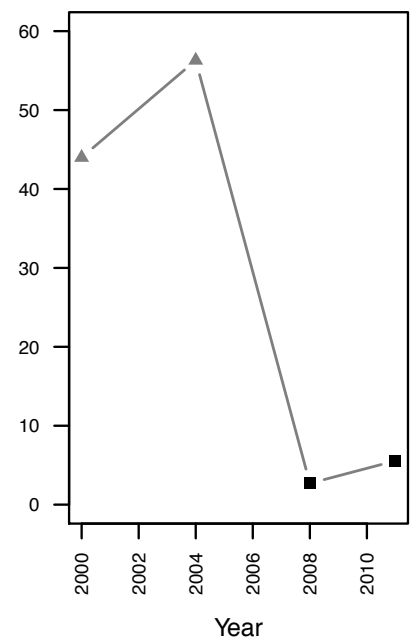

Source: CIS pre and post electoral surveys 2000-2011.

As shown in the upper-left panel in Figure 5, throughout the period, around $20 \%$ of respondents considered that the government's policy was better than the policy that would have been implemented by the main opposition party. When taking a closer look at incumbency periods, however, one can see that the evaluation of the Socialists' policy (2008 and 2011) was slightly worse than that of the PP (2000 and 2004). When splitting this analysis once again by ideological groups, it becomes clear that policy evaluations are ideologically informed. Extreme left and centre-left electorates increased significantly their positive evaluation of immigration policy when the PSOE was in power, whereas extreme right and centre-right electorates did so when the conservative PP was in office. The degree of ideological conditioning of policy evaluations, however, is larger for right-wing 
electorates. This means that right-wing voters are more easily convinced that the main rightwing party does a good job in immigration than left-wing individuals in relation to the main left-wing party. This slight advantage of the conservative PP in its positive association with immigration policies can also be observed among citizens who place themselves at the centre of the left-right scale. When the PSOE was in office, the difference between positive governmental evaluations and neutral or negative opposition evaluations was slightly smaller. Overall, these results suggest that ideological considerations play an important role in evaluating immigration policies in Spain. However, the right-wing PP also has a slight ownership advantage in being positively associated with immigration issues, especially among its closest electorates and, to a lesser extent, among central electorates.

\section{PARTY COMPETITION AND POLARIZATION AROUND IMMIGRATION}

We now evaluate the dynamics of the attention given to immigration and the policy positions on this issue by political parties in their party manifestos and in their public statements during the electoral campaigns. Party manifestos represent the most formalized communication of party positions about any given issue. However, campaign messages might or might not be fully consistent with the written manifestos, and as such they provide a complementary view of the parties' views on issues and, quite critically, of the range of views prevalent within the party elite. Although manifestos are low-key forms of communication of policy positions from the point of view of their capacity to reach the electorate, the advantage of using them as a source of information is that our access to party positions is not mediated by media attention. In contrast, party positions uncovered in media reporting of electoral campaigning are filtered by media agendas and considerations of news-worthiness (Rucht and Neidhardt, 1999; Koopmans, Statham, Giugni, and Passy, 2005). Thus, we divide our analysis of what parties say about immigration around elections in two: policy promises (as stated in manifestos) and electoral rhetoric (in their public statements as covered by quality newspapers).

\section{Policy promises}


We have coded manually all manifestos of the three main state-wide parties in the Spanish parliament ${ }^{8}$ - the centre-left Socialist Party (PSOE), the centre-right Popular Party (PP) and the radical-left United Left (IU) — for the six general elections held between 1993 and 2011. ${ }^{9}$ Figure 6 shows the dynamics of attention to immigration in party manifestos, while Figure 7 depicts the trends in the party positions on the issue. ${ }^{10}$

Throughout most of the period, IU has been the party to pay the most attention to immigration in their manifesto in a relatively sustained way but with a certain peak in 2004, prior to the peak of concern expressed by the public. However, in 2008 the PP and the PSOE substantially increased their attention to immigration, surpassing IU in that particular year. Overall, the pattern of attention of these latter two parties is fully congruent with the dynamics of concern with immigration of citizens discussed in the previous section, while the pattern for IU does not mimic the trends in public opinion. The results suggest that the core mainstream parties have responded to public concern by increasing their attention to immigration at about the same time: when voters are worried about immigration, most Spanish parties talk more about it; when other matters begin to preoccupy voters, they talk about it less. Moreover, the results in Figure 7 suggest that the two largest parties have gradually become less positive about immigration since 2000, and that they converge towards slightly more restrictive positions about the issue in the elections when immigration was most salient (2008).

Figure 6. Evolution of salience of immigration in party manifestos

\footnotetext{
${ }^{8}$ See Morales and Ros (2012) for an analysis that includes the main nationalist-regionalist parties in the Basque Country, Canary Islands, Catalonia and Galicia.

${ }^{9}$ The manual coding of manifestos proceeded in three steps. First, an exhaustive dictionary of keywords was used to help coders identify the parts of each manifesto that deal with immigration, to retrieve a corpus text of immigration-related statements that was then used for manual coding. The dictionary was produced in English, drawing on expert knowledge within the European Project SOM, and then translated into Spanish (see Appendix 1). Second, natural sentences (our units of analysis) were coded, as there is evidence that dividing (some) sentences into quasi-sentences is not necessary to produce valid position estimates (Däubler, Benoit, Mikhaylov, and Laver, 2012). The codebook used for the manual coding included a number of variables that capture the position of immigration in a nuanced way. Of relevance to this paper is the positional question ("What is the position toward the issue?" - ranging from "-1=Strongly restrictive to migrants/ conservative/ pronational residents/ mono-cultural" to "1=Strongly open to migrants/ progressive/ cosmopolitan/ multi-cultural"). Examples were included to aid coding (see Appendix 2). As a third step, in addition to coding the substantive positions on immigration, we calculated the number of words in all the sentences that constitute the shorter immigration-related corpus of the manifestos and computed their proportion in relation to the total number of words in each manifesto to create a proxy indicator of saliency of the immigration issue (see Appendix 3). More information about the methodological approach is available in Ruedin and Morales (2012).

${ }^{10}$ Party positions are the average value for each manifesto of all the individual position scores attributed to each natural sentence following the coding scheme described in Appendix 2.
} 


\section{Salience of immigration}

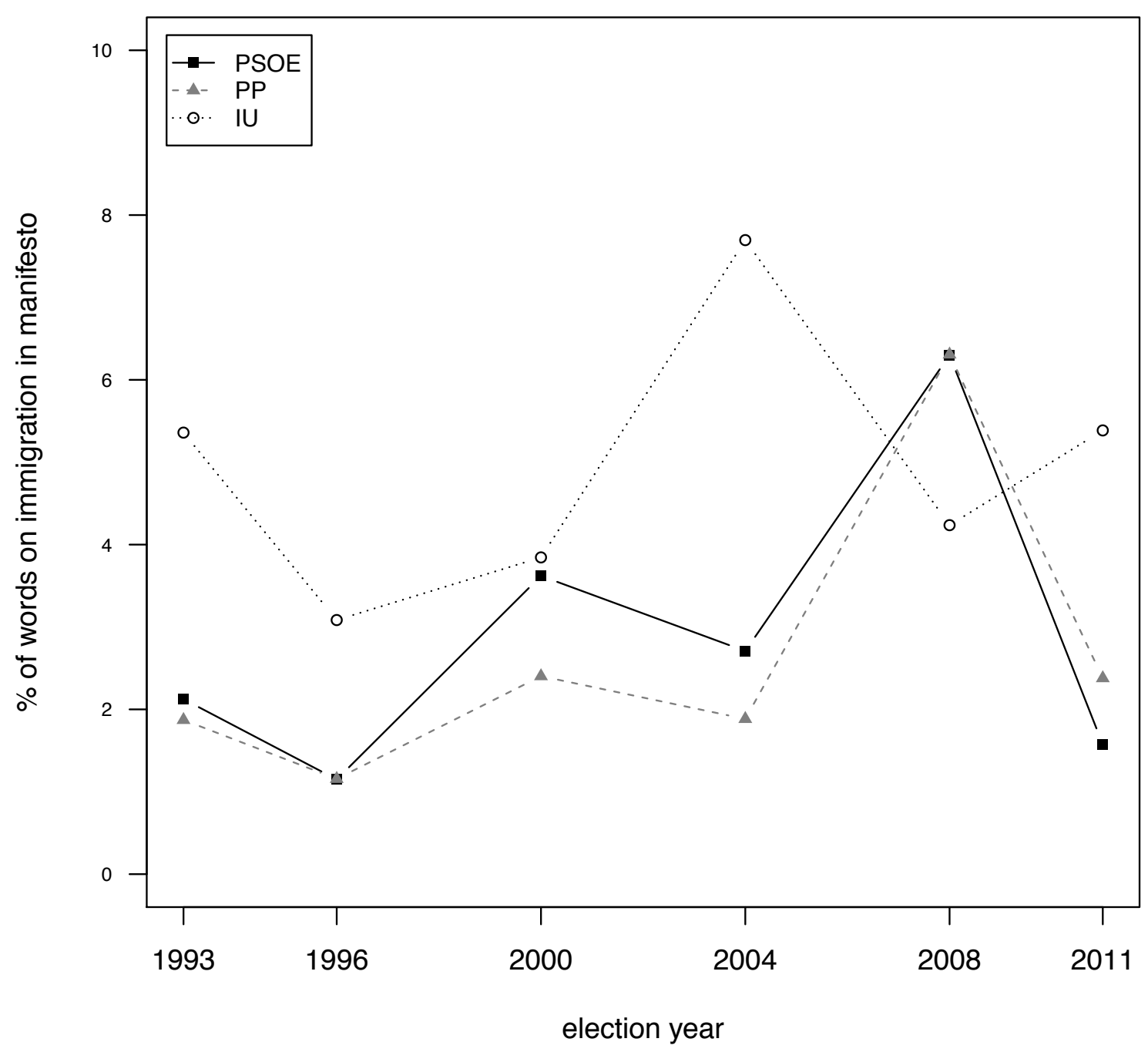

Source: SOM project, manual coding of party manifestos.

Furthermore, parties also converge in the ways in which they discuss immigration in party manifestos and which groups they are referring to when speaking of immigration. ${ }^{11}$ First, Spanish parties share the same referents when discussing immigration: they refer to immigrants as a general category or to unauthorised/irregular immigrants as a specific one.

Figure 7. Evolution of party positions on immigration (party manifestos)

\footnotetext{
${ }^{11}$ Our manifesto coding protocol allows us to examine the specific issue in relation to immigration that parties discuss in each sentence, as well as the 'objects' or social actors the statement refers to, and the way the statement is framed. See Ruedin and Morales (2012) for the full details on coding.
} 


\section{Position on immigration}

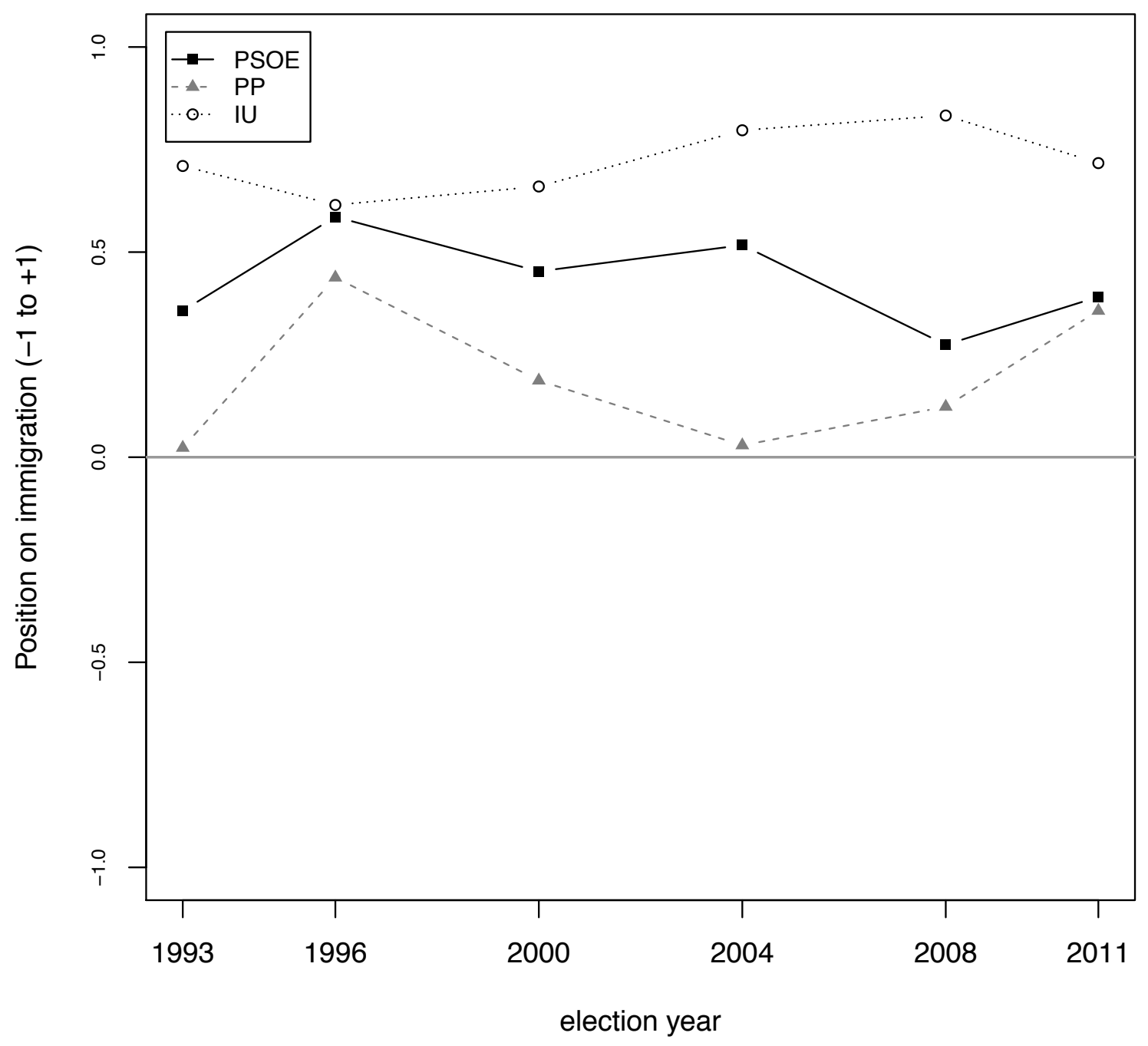

Source: SOM project, manual coding of party manifestos.

Note: $-1=$ Strongly restrictive to migrants/ conservative/ pro-national residents/mono-cultural; $1=$ Strongly open to migrants/ progressive/ cosmopolitan/ multi-cultural

Second, we find convergence also around the specific aspects in relation to which immigration is discussed. The four sub-issues most often cited in manifesto statements are crime, racism, voting rights and citizenship acquisition. Over time, most parties converge towards paying more attention to aspects that relate immigration to crime. Often, this does not mean that parties are equating immigrants to criminals, but that they mention issues related to immigrant smuggling, human trafficking, and other topics that connect immigration and criminality. The centre-right $\mathrm{PP}$ is the party that connects crime and immigration explicitly, but the attention afforded to these topics by the PSOE and IU between 2004 and 
2011 is also considerable. Tackling racism in society is also a major topic of attention in the manifestos of PSOE and IU. Similarly, issues related to voting rights and citizenship acquisition for immigrants have also been subjects of concern, especially for IU.

In relation to the frames used to justify their policy positions or statements, we do not find any convergence across parties. IU increasingly frames its position through moral and universal principles and gradually reduces the reference to instrumental justifications. However, there is no discernable trend in framing for either the PP or the PSOE. The PP has consistently framed its policy statements on immigration primarily with instrumental justifications, whereas the PSOE has oscillated between moral principles (1993-2000) and instrumental reasons (2004-2011). Identitarian frames are not very common in the statements of any of the parties.

Finally, our data from Spanish party manifestos does not provide much evidence of a relation between attention to immigration and inter-party agreement. Odmalm and Bale (2014) suggest that parties pay more attention to immigration or emphasise their ability to deal competently with the issue whenever there is greater inter-party agreement over the desired policy direction (Hypothesis 1). However, if we consider all parties that are relevant in the Spanish party system and use any measure of dispersion (e.g. the variance or the range) of the mean positions that parties have adopted in their manifestos (as depicted in Figure 7), the opposite seems to be the case. Inter-party disagreement has increased steadily since 1996, and parties have also increased the attention they afford to immigration in their platforms, peaking in 2008. In this regard, parties' attention does not seem driven by the degree of agreement or conflict it triggers in the political system, and parties just seem to pay more attention to immigration when it becomes a more salient issue for the electorate as a whole (see Figure 6). This notwithstanding, if we focus only on the PP and the PSOE, it is true that the year when they both paid most attention to immigration (2008) coincided with a period when their respective positions on the issue were quite close, whereas in the previous election (2004) their positions differed considerably and they chose not to focus much on immigration. Yet, we also find an equal number of examples when their positions were close and they did not pay attention to immigration (1996 and 2011). 


\section{Electoral rhetoric}

Despite the advantages of party manifestos, they can be artificially consistent sources of party positions. They also are problematic when parties strategically choose to keep silent about issues in which they feel they do not have a competitive edge. Thus, we have undertaken a systematic analysis of the public statements made by political parties during the electoral campaigns of 2000, 2004, 2008 and 2011 in order to ascertain how the electoral campaign rhetoric might differ from their manifestos. For this purpose we have scanned the political, economic and society sections of the newspaper El Pais in the 3 months prior to each election. ${ }^{12}$ Every statement, reference or action in relation to immigration by any political actor was considered a claim and coded as such, following a reduced version of the coding system described by Berkhout and Sudulich (2011). As for the party manifestos, we have information about the party that made the claim, the pro- or anti-immigrant position of the claim, as well as the topic and frame.

Figure 8 shows the number of claims per month retrieved for each of the four elections. The results clearly indicate that immigration figured prominently in the 2000 and 2008 elections, whereas it was only a less relevant issue in 2004 and almost an irrelevant one in 2011. The contrast between 2000 and 2004 is at odds with our findings about the salience of immigration in party manifestos depicted in Figure 6 . The reason for this is that immigration was never intended to become a major topic of the electoral campaign in 2000. However, two main events put immigration at the centre of the political discussion in the months prior to the elections. First, a big political row around the reform of the main law related to immigration (Ley de Extranjería, L.O. 4/2000) irrupted during the electoral campaign period due to the PP being unable to rally the required parliamentary support for their intended reform (as the PP formed a minority government in the 1996-2000 term). Second, the most serious riots related to immigration that Spain has ever seen to this date - the El Ejido riots - kicked off precisely one month before the elections. Almost all the statements on immigration during the three months of the electoral campaign in 2000 revolved around these two events. In fact, the discussion of electoral positions on immigration was minimal in 2000, beyond the PP reaffirming its intention to reform the immigration law if they were to win a majority, and the

\footnotetext{
${ }^{12}$ Formally, electoral campaigns in Spain only run during the two weeks prior to the elections. Informally, however, political parties are in electoral campaign mood much earlier than that. Although there is no set date that can be clearly considered as the starting date of the campaign, the nomination of candidates and the public issuing of the party manifesto typically happen within these three months.
} 
opposition parties stating their opposition to the plans of the PP. There is no suggestion in the scholarship on Spanish electoral behaviour, however, that immigration figured in any relevant way among the main voting determinants in that election.

Figure 8. Statements about immigration made by parties during electoral campaigns

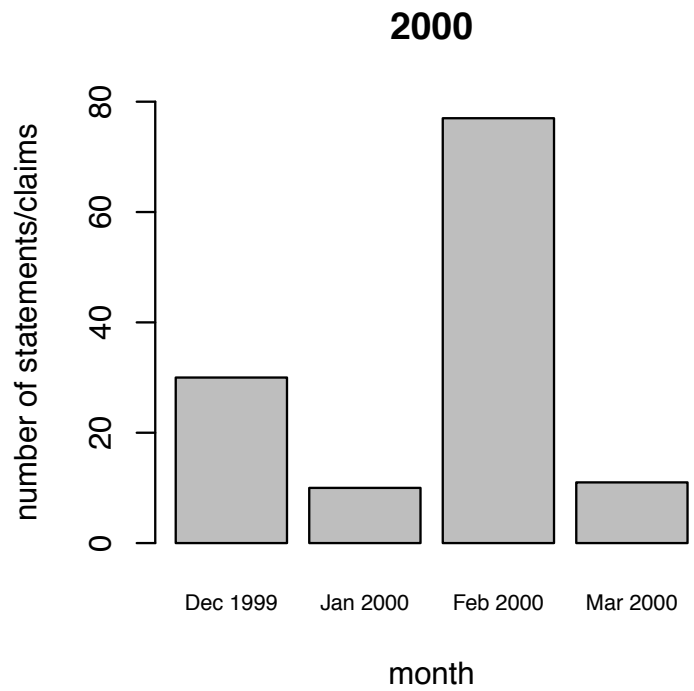

2008

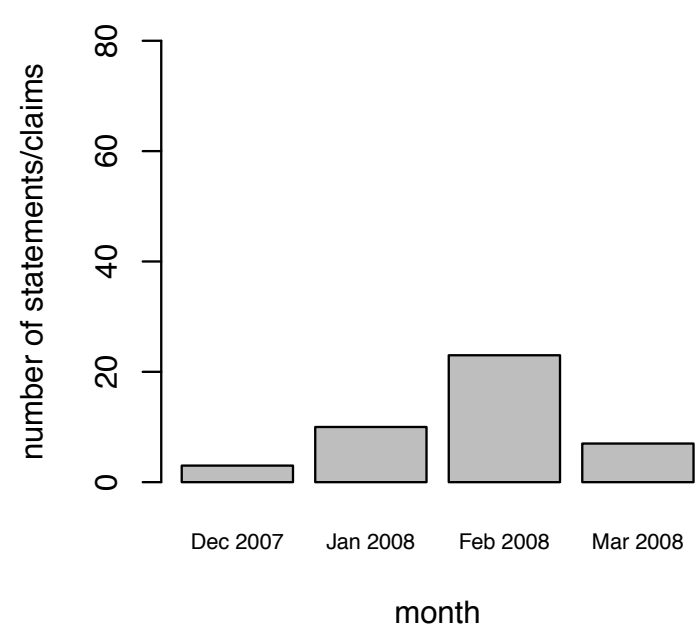

2004

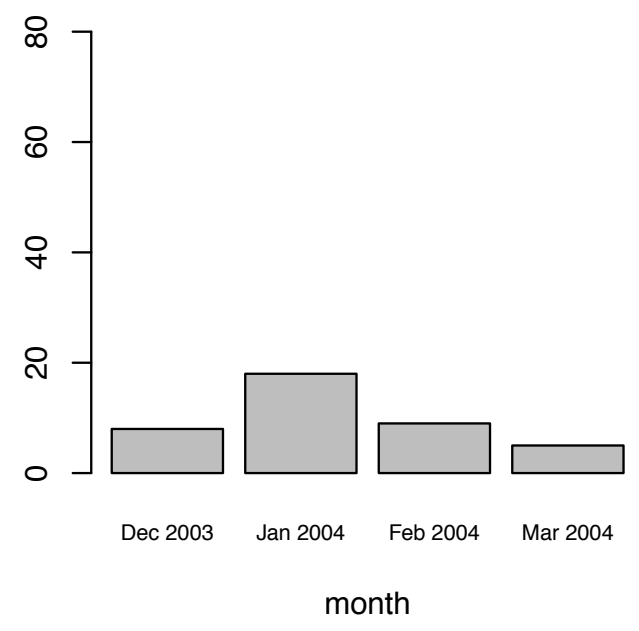

2011

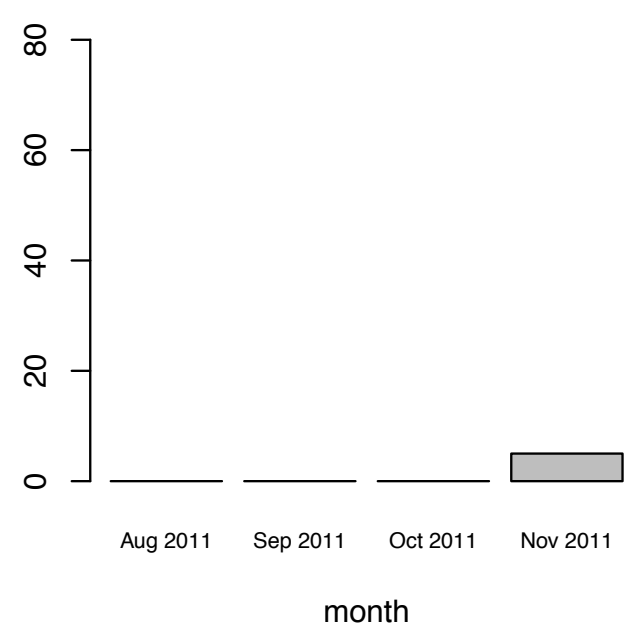

In contrast, immigration was the subject of explicit political debate among the main parties during the electoral campaigns of 2004 and 2008. In 2004, the PSOE presented its proposals on immigration as early as December 2003, and in February 2004 the leader of the left-wing IU (Gaspar Llamazares) recognised that the immigration issue could win votes for the governing PP, as there was an increasing anti-immigrant sentiment in traditional working- 
class areas. Moreover, immigration was frequently among the topics discussed during the electoral rallies that took place in March 2004. The PP candidate - Mariano Rajoy emphasised the pledge to combat unauthorised immigration, while the Socialist candidate José Luis Rodríguez Zapatero - insisted on the need to regularise immigrants to give them access to the labour market. Nevertheless, the discussion around immigration during the campaign ended up being of very little relevance to the final electoral result, as the March 11 Madrid bombings took everyone by surprise. Given that the PP insisted for quite some time that ETA, rather than Al-Qaeda, had perpetrated the bombings, the discussions about the attack were always framed around the issue of the credibility of the PP and its alleged attempts to manipulate the public to its electoral advantage, rather than around immigration.

In 2008, the immigration issue started to appear prominently in the electoral debate as soon as December 2007. Zapatero and the PSOE initiated the campaign with a discourse that combined 'hawkish' messages about their intention to combat unauthorised immigration through border control with 'dovish' messages that proposed development aid policies for Africa as a means to reduce the inflow, or more speedy family reunion policies for immigrants. The Socialists also emphasised the need to combat racism and xenophobia and their intention to implement plans to protect all immigrant women who were victims of abuse. In sharp contrast, the electoral campaign of the PP that year revolved around a proposal by Rajoy that immigrants should sign an 'integration contract', proposals to change the visa policy to a 'points system', and to prevent Muslim women from using the veil in public. For the first time, the integration debate had entered the electoral campaign in Spain, and the PP approached it from all angles, to a point that some high-ranking members of the government started making 'politically incorrect' claims suggesting immigrants had a negative impact on the economy and welfare provisions.

To a certain extent, this strategy by the PP to adopt a tough discourse on immigration backfired. Several parties, particularly the PSOE and IU, accused the centre-right party of adopting extreme-right positions and of inciting racism and xenophobia. The PP had to reword several of its proposals on various occasions, and defend themselves from the accusations of xenophobia. ${ }^{13}$ An interview with a PP leader (Gabriel Elorriaga) on $1^{\text {st }}$ March 2008 confirmed that the emphasis on immigration by the PP was meant to depress the turnout

\footnotetext{
${ }^{13}$ In relation to this, our results show a sharp increase in the proportion of statements/claims made by political parties that are responding or criticising a political opponent: from $11 \%$ in 2000 to $28 \%$ in 2008 .
} 
of traditional Socialist voters who were disgruntled by Socialist policies. However, the PP did not win the elections and the general evaluation was that the handling of the immigration issue did not have any clear electoral payoff. Though the PP strategy was to undermine the public perception of competence of the Socialists on immigration, the PSOE was more or less successful in counter-attacking with a discourse that blamed the situation on previous failed policies of the PP in the 2000-2004 term. In fact, our results shown in Figure 4 suggest that the PSOE did not go down in evaluations of competence on immigration between April 2006 and October 2008, suggesting that the PP's strategy failed.

As a consequence, immigration virtually disappeared from the electoral scene in the 2011 elections. The magnitude of the economic crisis absorbed all the attention, but it is worth emphasising that the economic crisis could have triggered a greater attention to unwanted immigration in times of hardship, as has been the case in Greece. We can only speculate around the reasons for this lack of heightened politicization of immigration in Spain during the post-2008 economic crisis period. Partly, this is likely to be due to the perception - and reality - of immigration flows diminishing considerably. In fact, the statistics suggest that a non-negligible number of immigrants left the country as the crisis got worse, and since 2011 out-going migration from Spain has become the focus of attention instead. However, it is also quite likely that, with no pressure from any significant anti-immigrant party to the right of the PP, the two main parties did not feel any need to keep politicising an issue that had lost much steam. $^{14}$

Overall, the results suggest that attention to immigration by parties is primarily driven mainly by the salience of the issue in the electorate and also by strategic calculations about electoral gains and losses. Yet issue ownership does not seem to be critical in determining how parties position themselves on immigration. In fact, the Socialists discussed immigration as much as the PP during the 2008 elections, when the issue was most prominent on the electoral agenda. And, whereas the PP adopted an increasingly restrictive position both in its manifestos and, especially, in its public statements during electoral campaigns, the PSOE sustained a moderately liberal position throughout the whole period. ${ }^{15}$ Given that voters at the time were becoming more negative about immigration, and given that they were growing more sceptical

\footnotetext{
${ }^{14}$ For an analysis of the factors that might explain the absence of a relevant state-wide radical right party in Spain, see Llamazares and Ramiro (2007).

${ }^{15}$ The mean values for the variable on position for the parties' public statements are provided in Appendix 4.
} 
about the Socialists' competence on the issue, this is not the behaviour we would have expected from the PSOE under the premises of issue ownership competition.

\section{DISCUSSION AND CONCLUSIONS}

In an era of profound demographic change due to immigration flows, increasing salience of immigration concerns in public opinion and stabilisation of radical right parties in several European countries, the Spanish mainstream parties have also started to incorporate immigration into their patterns of electoral competition. The analysis of the structure of political competition over the immigration issue in Spain unveils a nuanced balance between spatial and valence considerations.

A number of findings point out to valence strategies (based on salience and images of party competence) to deal with immigration. Our party manifesto analyses show that the largest state-wide parties (PP and PSOE) converged over time around somewhat more restrictive positions in relation to immigration. Moreover, the specific issue framing in parties' official discourses shows significant similarities, especially in terms of conceptual framing and ways to categorise and refer to immigrants. From a public opinion perspective, the evolution of anti-immigrant hostility over time follows a markedly similar course across different ideological spaces. Although right-wing voters tend to be more anti-immigrant, the temporal evolution and convergence of opinions resemble those of classical valence issues. As a consequence, competence matters - especially to voters who place themselves around the middle of the left-right spectrum.

Valence considerations, however, are not enough to understand party competition around the immigration issue in Spain. Some perceptions of party competence in public opinion are very much influenced by ideological heuristics, especially at the extremes of the spectrum. Leftand right-wing electorates tend to think of the party in their respective ideological block as more competent in handling immigration. The same applies to public evaluations of the immigration policies implemented by different governments in Spain. Even if the PP seems to have a slight ownership advantage and to be perceived more positively by centrist voters and by its own electorate, satisfaction with immigration policy is ideologically driven. 
Moreover, we did not find evidence supporting the hypothesis that inter-party agreement increases parties' valence strategies (Hypothesis 1) - a core assumption of valence theories of party competition. In fact, we found the opposite, namely greater attention being paid to immigration when parties were more polarized around the issue (or higher polarization whenever immigration was prominent). It is difficult to say whether polarization drives salience or the other way around. However, a careful reading of the newspaper reports of the electoral campaigns we have covered suggests that the salience of the issue forces parties to position themselves on the different aspects related to immigration in order to attend to the news cycle. This, in turn, forces them to become less ambiguous about their positions, thus fostering polarization — which, again, feeds salience.

Equally, we did not find evidence that issue ownership was the main driver of parties' attention to the issue of immigration (Hypothesis 2). If that were the case, we would, for example, have expected the Socialists to downplay immigration throughout the period, especially in 2008, given their relative disadvantage in voters' perceptions of competence and the additional incumbency penalty. Yet, the PSOE has not really downplayed immigration in its manifesto or in its public discourse. The Socialists have paid as much attention to the issue as the PP and, although their platforms have converged slightly towards more restrictive positions, they have remained 'liberal' or 'pro-immigrant' throughout the period. This suggests again that a more nuanced combination between spatial and valence frameworks of analysis is needed to understand the competition dynamics around the immigration issue in Spain.

In relation to intra-party ideological tensions (Hypothesis 3), the available data do not allow us to offer an in-depth analysis of this aspect. Casual inspection of the materials analysed suggests that any internal divergences around the issue of immigration in Spanish parties are kept relatively muted. Even so, dissenting views around immigrant integration issues exist between local/regional politicians and national-level ones. This happened during the 2008 elections in the PP, when Mariano Rajoy publicly disagreed with the regional president of Madrid, Esperanza Aguirre, on account of their respective positions around granting local voting rights to non-EU foreigners. Moreover, an analysis of the heterogeneity of the claimsmaking of the three main state-wide parties as reported in newspapers, suggests that IU is very consistent in making pro-immigrant or liberal claims, whereas the positions reflected in 
the statements of PP and PSOE representatives vary much more. The PSOE has become more heterogeneous over time, whereas the PP has not changed much. However, there is no clear cleavage or divide within any of the Spanish parties around the immigration issue. Indeed, Spanish parties are rarely deeply divided internally on any issue - except on the centreperiphery cleavage and, to a much lesser extent, moral issues (such as abortion and same-sex marriage).

Our results for the Spanish case suggest that issue salience and valence considerations have some relevance, but also that parties have a tendency to stick to their long-held views about immigration despite the pressures they perceive from the electorate. Thus, a certain amount of friction in how parties react to a changing environment (Walgrave and Nuytemans, 2009) seems to be in place in the Spanish case. Given that mass immigration is a relatively recent phenomenon in Spain, this should make us cautious about making any excessively bold statements about how the country's parties handle the issue. Public opinion, as we show, matters. If it moves, so will parties after a time lag. As a result valence-style competition and attempts to establish issue ownership on immigration might indeed become more common in the future.

\section{REFERENCES}

Adams, J., Clark, M., Ezrow, L., \& Glasgow, G. (2006) Are Niche Parties Fundamentally Different from Mainstream Parties? The Causes and the Electoral Consequences of Western European Parties' Policy Shifts, 1976-1998. American Journal of Political Science, 50(3): 513-529.

Bale, T. (2008) Turning round the telescope. Centre-right parties and immigration and integration policy in Europe. Journal of European Public Policy, 15(3): 315-330.

Bale, T., Green-Pedersen, C., Krouwel, A., Luther, K.R., \& Sitter, N. (2010) If You Can't Beat Them, Join Them? Explaining Social Democratic Responses to the Challenge from the Populist Radical Right in Western Europe. Political Studies, 58(3): 410-426.

Bélanger, É. \& Meguid, B.M. (2008) Issue salience, issue ownership, and issue-based vote choice. Electoral Studies, 27(3): 477-491.

Berkhout, J. \& Sudulich, M.L. (2011) Codebook for Political Claims Analysis, SOM Working Papers. Neuchâtel: University of Neuchâtel.

Boomgaarden, H.G. \& Vliegenthart, R. (2009) How news content influences antiimmigration attitudes: Germany, 1993-2005. European Journal of Political Research, 48(4): 516-542.

Bornschier, S. (2010) The New Cultural Divide and the Two-Dimensional Political Space in Western Europe. West European Politics, 33(3): 419-444. 
Brighton, P. \& Foy, D. (2007) News values: Sage Publications Limited.

Budge, I. \& Farlie, D.J. (1983) Explaining and predicting elections: Issue effects and party strategies in twenty-three democracies: Allen \& Unwin London.

Cebolla, H. \& González, A. (2008) La inmigración en España (2000-2007). De la gestión de los flujos a la integración de los inmigrantes. Madrid: Centro de Estudios Políticos y Constitucionales.

Däubler, T., Benoit, K., Mikhaylov, S., \& Laver, M. (2012) Natural Sentences as Valid Units for Coded Political Texts. British Journal of Political Science, forthcoming.

Downs, A. (1957) An Economic Theory of Democracy. New York: Harper \& Bros.

Enelow, J.M. \& Hinich, M.J. (1984) The spatial theory of voting: An introduction: Cambridge University Press.

Green-Pedersen, C. (2007) The Growing Importance of Issue Competition: The Changing Nature of Party Competition in Western Europe. Political Studies, 55(3): 607-628.

Hernández Carr, A. (2011) ¿La hora del populismo?: elementos para comprender el "éxito" electoral de Plataforma per Catalunya. Revista de Estudios Políticos(153): 47-74.

Jennings, W. (2009) The Public Thermostat, Political Responsiveness and Error-Correction: Border Control and Asylum in Britain, 1994-2007. British Journal of Political Science, 39(4): 847-870.

Koopmans, R., Statham, P., Giugni, M.G., \& Passy, F. (2005) Contested Citizenship. Immigration and Cultural Diversity in Europe. Minneapolis: University of Minnesota Press.

Kriesi, H., Grande, E., Lachat, R., Dolezal, M., Bornschier, S., \& Frey, T. (2006) Globalization and the transformation of the national political space: Six European countries compared. European Journal of Political Research, 45(6): 921-956.

Kriesi, H., Grande, E., Lachat, R., Dolezal, M., Bornschier, S., \& Frey, T. (2008) West European politics in the age of globalization. Cambridge: Cambridge University Press.

Llamazares, I. \& Ramiro, L. (2007) Les espaces politiques restreints de la droite radicale espagnole. Une analyse des facteurs politiques de la faiblesse de la nouvelle droite en Espagne. Pôle Sud-Revue de Science Politique, 26: 137-152.

Meguid, B.M. (2005) Competition Between Unequals: The Role of Mainstream Party Strategy in Niche Party Success. American Political Science Review, 99(03): 347-359.

Méndez, M., Cebolla, H., \& Pinyol, G. (2013) ¿Han cambiado las percepciones sobre la inmigración en España?, Zoom Político. Madrid: Fundación Alternativas.

Morales, L. \& Ros, V. (2012) La politización de la inmigración en España en perspectiva comparada. Barcelona: CIDOB.

Morales, L.\& Ros, V.\& Berkhout, J.\& Cunningham, K.\& Peintinger, T.\& Ruedin, D.\& Sudulich, M.L., et al. (2012) Comparative Data Set of Immigration-Related Statistics 1995-2009, Support and Opposition to Migration Project. In U.o.M. Institute for Social Change (ed.). 2 ed. Cambridge, MA: Harvard Dataverse Network.

Moreno, F.J. (2004) The evolution of immigration policies in Spain. Between external constraints and domestic demand for unskilled labour. Madrid: Instituto Juan March.

Odmalm, P. \& Bale, T. (201X) Immigration into the Mainstream: Conflicting Ideological Streams, Strategic Reasoning and Party Competition. Acta Politica, XX(X): XXX-XXX.

Petrocik, J.R. (1996) Issue ownership in presidential elections, with a 1980 case study. American Journal of Political Science, 40(3): 825-850.

Rucht, D. \& Neidhardt, F. (1999) Methodological issues in collecting protest event data: units of analysis, sources and sampling, coding problems. In: D. Rucht, R. Koopmans, and F. Neidhardt (eds.) Acts of Dissent. New Developments in the Study of Protest: Oxford: Rowman \& Littlefield Publishers, pp. 65-89. 
Ruedin, D. \& Morales, L. (2012) Obtaining Party Positions on Immigration from Party Manifestos. Paper presented at the Elections, Public Opinion and Parties (EPOP) conference, Oxford.

van der Brug, W. \& van Spanje, J. (2009) Immigration, Europe and the 'New' Cultural Cleavage. European Journal of Political Research, 48(2): 308-334.

van Spanje, J. (2010) Contagious Parties. Party Politics, 16(5): 563-586.

van Spanje, J. (2011) Keeping the rascals in: Anti-political-establishment parties and their cost of governing in established democracies. European Journal of Political Research, 50(5): 609-635.

Walgrave, S. \& Nuytemans, M. (2009) Party manifesto change: friction or smooth adaptation? A comparative analysis in 25 countries (1945-1998). American Journal of Political Science, 53(1): 190-206. 
APPENDIX 1. Dictionary of keywords with Spanish translation used within brackets.

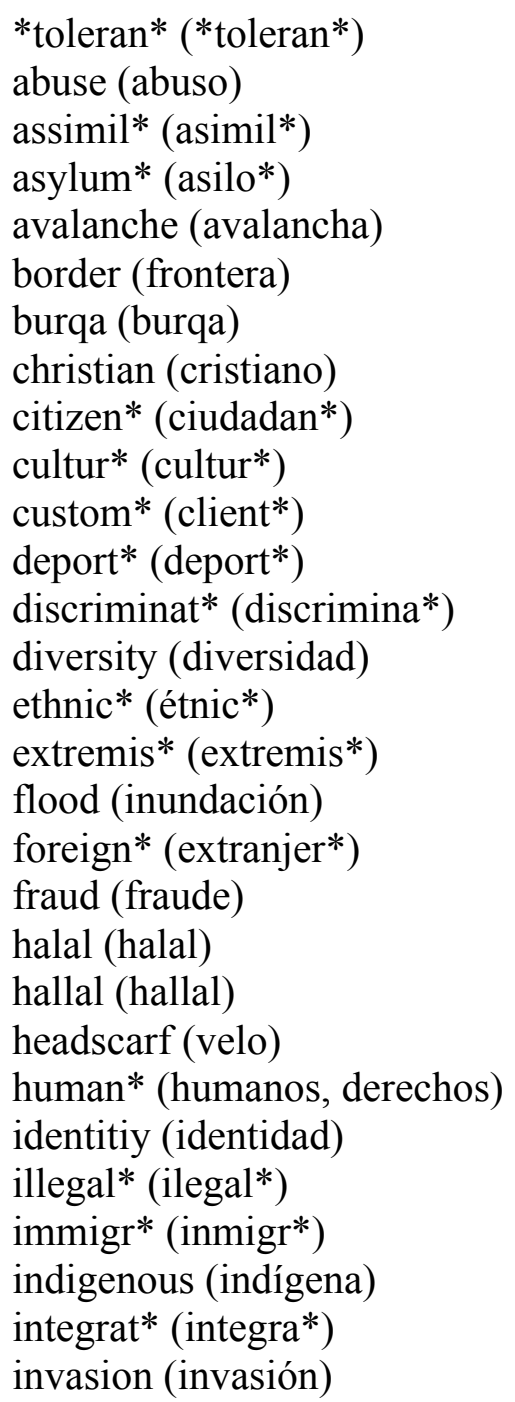

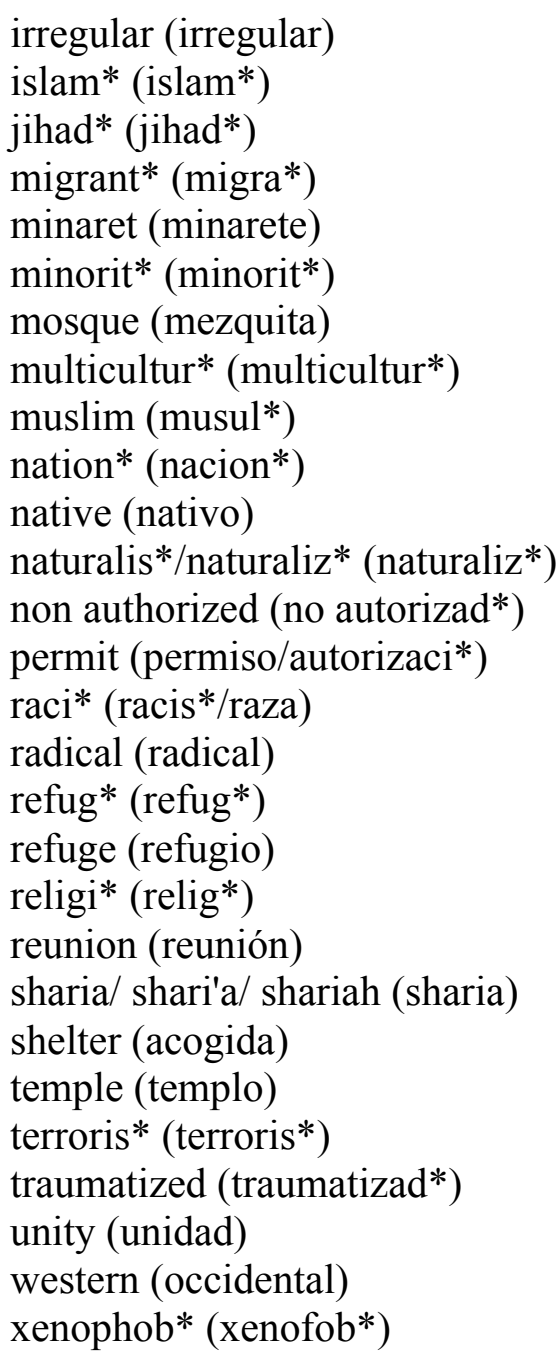


APPENDIX 2. Coding scheme used for the position variable employed in the coding of manifestos and electoral statements reported in newspapers.

\section{Position}

-1 'Strongly restrictive to migrants/conservative/pro-national residents/mono-cultural '

- 0.5 'Somewhat restrictive to migrants/conservative/pro-national residents/mono-cultural '

0 'Neutral/ambivalent/technocratic/pragmatic'

0.5 'Somewhat open to migrants/progressive/cosmopolitan/multi-cultural'

1 'Strongly open to migrants/progressive/cosmopolitan/multi-cultural'

9 'Unclassifiable'. 
APPENDIX 3. Manifestos used and salience measure

\begin{tabular}{|c|c|c|c|c|c|c|}
\hline Party & Year & $\begin{array}{l}\text { A. Full length } \\
\text { of manifesto } \\
\text { (words) }\end{array}$ & $\begin{array}{l}\text { B. Parts on } \\
\text { immigration in } \\
\text { manifesto } \\
\text { (words) }\end{array}$ & $\begin{array}{c}\text { Salience } \\
(\mathrm{B} / \mathrm{A})\end{array}$ & $\begin{array}{c}\text { Average } \\
\text { position on } \\
\text { immigration }\end{array}$ & $\begin{array}{c}\text { Standard } \\
\text { deviation of } \\
\text { position }\end{array}$ \\
\hline IU & 1993 & 65,959 & 3,535 & 0.054 & 0.71 & 0.33 \\
\hline IU & 1996 & 157,073 & 4,845 & 0.031 & 0.615 & 0.38 \\
\hline IU & 2000 & 116,753 & 4,489 & 0.038 & 0.66 & 0.39 \\
\hline IU & 2004 & 48,570 & 3,738 & 0.077 & 0.797 & 0.29 \\
\hline IU & 2008 & 51,155 & 2,167 & 0.042 & 0.833 & 0.31 \\
\hline IU & 2011 & 43,445 & 2,340 & 0.054 & 0.717 & 0.36 \\
\hline PP & 1993 & 42,849 & 802 & 0.019 & 0.023 & 0.55 \\
\hline PP & 1996 & 54,390 & 629 & 0.012 & 0.438 & 0.48 \\
\hline PP & 2000 & 54,973 & 1,321 & 0.024 & 0.187 & 0.40 \\
\hline PP & 2004 & 85,034 & 1,602 & 0.019 & 0.029 & 0.46 \\
\hline PP & 2008 & 78,777 & 4,969 & 0.063 & 0.123 & 0.51 \\
\hline PP & 2011 & 43,973 & 1,046 & 0.024 & 0.357 & 0.36 \\
\hline PSOE & 1993 & 33,470 & 711 & 0.021 & 0.357 & 0.55 \\
\hline PSOE & 1996 & 68,816 & 791 & 0.011 & 0.586 & 0.40 \\
\hline PSOE & 2000 & 33,148 & 1,200 & 0.036 & 0.453 & 0.53 \\
\hline PSOE & 2004 & 87,745 & 2,376 & 0.027 & 0.517 & 0.48 \\
\hline PSOE & 2008 & 102,057 & 6,430 & 0.063 & 0.274 & 0.52 \\
\hline PSOE & 2011 & 63,658 & 1,002 & 0.016 & 0.391 & 0.35 \\
\hline
\end{tabular}

Source: Manual party manifesto coding, SOM project. 
APPENDIX 4. Positions on immigration in public statements

\begin{tabular}{lcccc}
\hline Party & Year & $\begin{array}{c}\text { Total number } \\
\text { of claims }\end{array}$ & $\begin{array}{c}\text { Average } \\
\text { position on } \\
\text { immigration }\end{array}$ & $\begin{array}{c}\text { Standard } \\
\text { deviation of } \\
\text { position }\end{array}$ \\
\hline IU & 2000 & 6 & 0.5 & 0 \\
IU & 2004 & 6 & 0.33 & 0.68 \\
IU & 2008 & 2 & 1 & 0 \\
IU & 2011 & 0 & n.a. & n.a. \\
PP & 2000 & 76 & -0.25 & 1.41 \\
PP & 2004 & 21 & -0.21 & 0.49 \\
PP & 2008 & 18 & -0.56 & 0.56 \\
PP & 2011 & 3 & -0.83 & 0.29 \\
PSOE & 2000 & 25 & 0.52 & 0.45 \\
PSOE & 2004 & 8 & 0.25 & 0.37 \\
PSOE & 2008 & 18 & 0.28 & 0.51 \\
PSOE & 2011 & 1 & 0 & 0 \\
\hline Source: Authors coding of newspaper editions of $E l$ País.
\end{tabular}

Source: Authors' coding of newspaper editions of El País. 